\title{
Corporate Governance in Banking Sector: A Case study of State Bank of India
}

\author{
Dr. Srinivasa Rao Chilumuri M.Com.,M.B.A.,Ph.D., \\ Assistant Professor, Dept. of Commerce, Govt. Degree College (W), Srikalahasti, A.P. India.
}

\begin{abstract}
The issue of corporate governance has come up mainly in the wake up economic reforms characterized by liberalization and deregulation. Corporate governance has at its backbone a set of transparent relationships between an institution's management its board, shareholders and other stakeholders.

The objective of the research paper is to evaluate the corporate governance practice in banking sector particularly in the State Bank of India. For evaluation purpose, this research paper is divided into two parts. With the help of secondary data, this work was analyzed and based on different elements of the practice of corporate governance evaluated in State Bank of India.

The Indian banking system is among the healthier performers in the world. In the liberalized economic environment and integration of the country at present the banking sector in India cannot ignore the importance of corporate governance.

The corporate governance philosophy of banks is the pursuit of sound business ethics and strong professionalism that aligns the interests of all stakeholders and the society.

The State Bank of India is the largest bank amongst all public and private sector banks in India. It is the second largest bank in the world measured by the number of branch offices. The bank provides various domestic, international and NRI products and services through its vast network in India and overseas.

State Bank of India needs to ensure good corporate governance in order to achieve excellence, transparency, maximization shareholders value and wealth.

Keywords: Corporate Governance, Banking Sector, State Bank of India.
\end{abstract}

\section{INTRODUCTION}

The issue of corporate governance has come up mainly in the wake up of economic reforms characterized by liberalization and deregulation.

According to OECD, the corporate governance structure specifies the distribution of rights and responsibilities among different participants in the corporation, such as, the board, managers, shareholders and other stakeholders and it also spells out the rules and procedures for making decisions on corporate affairs.

Corporate governance is exclusively of board of directors in a manner that it becomes a way of organizational life and not merely written rules or regulations or code of ethics. Ethics and transparency are cardinals of corporate governance.

\section{WORLD SCENARIO}

The seeds of modern corporate governance were probably sown by the watergate scandal in the USA. Subsequent investigations by US regulatory and legislative bodies highlighted control failures that had allowed several major corporations to make illegal political contributions and bribe government officials. While these developments in the US stimulated debate in the UK, a spate of scandals and collapses in that country in the late 1980s and early 1990s led shareholders and banks to worry about their investments. Several companies in UK which saw explosive growth in earnings in the 1980s ended the decade in a memorably disastrous manner.

In May 1991, the London Stock Exchange set up a committee under the chairmanship of Sir Arian Cadbury to help raise the standards of corporate governance and the level of confidence in financial reporting and auditing by setting out clearly what it sees as the respective responsibilities of those involved and what it believes is expected of them. The committee investigated accountability of the board of directors to shareholders and to the society. It submitted its report and the associated 'code of best practices' in December 1992 wherein it spelt out the methods of governance needed to achieve a balance between the essential powers of the board of directors and their proper accountability.

Contemporary corporate governance started in 1992 with the Cadbury report in the UK. Cadbury was the result of several high profile company collapses and was concerned primarily with protecting weak and widely dispersed shareholders against self-interested directors and managers. 


\section{INDIAN SCENARIO}

The corporate governance initiative in India was not triggered by any serious nationwide financial, banking and economic collapse. The initiative in India was driven by The Confederation of Indian Industry. In December 1995, CII set up a task force to design a voluntary code of corporate governance. The final draft of this code was widely circulated in 1997. In April 1998, the code was released. It was called "Desirable Corporate Governance: A Code".

Following CII's initiative, the Securities and Exchange Board of India (SEBI) set up a committee under Kumar Mangalam Birla to design a mandatory-cum-recommendatory code for listed companies. The Birla Committee Report submitted in February 2000 and it was approved by SEBI in December 2000. The report became mandatory for listed companies through the listing agreement and implemented according to a rollout plan. Following CII and SEBI, the Department of Company Affairs (DCA) modified the companies Act 1956, to incorporate specific corporate governance provisions regarding independent directors and audit committees.

\section{OBJECTIVES AND METHODOLOGY}

The objective of the research paper is to evaluate the corporate governance practice in banking sector through a case study of the State Bank of India. For evaluation purpose, this research paper divided into two parts. Based on different elements of and with the help of secondary data, this work has analyzed and evaluated the practice of corporate governance in State Bank of India.

In the first part, the concepts of corporate governance like evolution of corporate governance in world and Indian scenario, role and importance of corporate governance in banking sector has been discussed. The second part analyses the practice of corporate governance as determined in State Bank of India with the help of elements like board practices, stakeholders and transparent disclosure of information.

\section{CORPORATE GOVERNANCE IN INDIAN BANKING SECTOR}

The corporate governance practice is important for banks in India because majority of the banks are in public sector, where they are not only competing with one another but with other players in the banking system. Further, with restrictive support available from the government for further capitalization of banks, many banks may have to go for public issues, leading to transformation of ownership.

The banks form an integral part of the economy of the country and any failure in a bank might have a direct bearing on the financial health of the country.

The Basel committee on banking supervisory authorities was established by the Central Bank Governors of the G10 developed countries in 1975. The Basel committee in the year 1999 had brought out certain important principles on corporate governance for banking organizations which, more or less have been adopted in India. The minimum impact of recession on Indian economy was because of strong and effective nature of banking sector in India.

\section{CORPORATE GOVERNANCE IN STATE BANK OF INDIA}

State Bank of India is the country's largest commercial bank in terms of profits, assets, deposits, branches and employees. With over 200 years of existence, State Bank group has a presence in 33 countries and extensive network of more than 18,000 branches and 26,000 plus ATMs and 100 million accounts across the country. The only Indian Bank to feature in the Fortune 500 list, SBI has 5 Associate banks and 7 Subsidiaries arguably the largest in the world. With millions of customers across the country, SBI offers a complete range of banking products and services with cutting edge technology and innovative banking model.

State Bank of India is committed to the best practices in the area of corporate governance. The sound corporate governance practice in State Bank of India would lead to effective and more meaningful supervision and could contribute to a collaborative working relationship between bank management and bank supervisors.

Based on different elements like boards practices, stakeholder's services and transparent disclosure of information the practice of corporate governance in state bank of India was assessed.

\section{Central Board}

\section{BOARD PRACTICES}

The central board of directors was constituted according to the SBI Act 1955. The bank's central board draws its powers from and carries out its functions in compliance with the provisions of State Bank of India Act \& Regulations 1955. Its major roles include, among others, overseeing the risk profile of the bank; monitoring the integrity of its business and control mechanisms; ensuring expert management, and maximising the interests of its stakeholders. The central board has constituted seven board level committees. 
7.1. Audit Committee of the Board: ACB provides direction as well as oversees the operation of the total audit function in the bank. Total audit function implies the organizational, operational, quality control of internal audit and inspection within the bank, follow-up on the statutory audit and compliance with RBI inspection.

It also appoints statutory auditors of the bank and reviews their performance from time to time.ACB reviews the bank's financial, risk management, IS audit policies and accounting policies of the bank to ensure greater transparency.

7.2. Risk Management Committee of the Board: RMCB was constituted to oversee the policy and strategy for integrated risk management relating to credit risk, market risk and operational risk.

7.3. Shareholders'/Investors' Grievance Committee of the Board : SIGCB was formed to look into the redressal of shareholders' and investors' complaints regarding transfer of shares, non-receipt of annual report, non-receipt of interest on bonds/declared dividends, etc.

7.4. Special Committee of the Board for Monitoring of Large Value Frauds: The major functions of the committee are to monitor and review all large value frauds with a view to identifying systemic lacunae, if any, reasons for delay in detection and reporting, monitoring progress of CBI / Police investigation, recovery position and reviewing the efficacy of remedial action taken to prevent recurrence of frauds.

7.5. Customer Service Committee of the Board: CSCB was constituted to bring about ongoing improvements on a continuous basis in the quality of customer service provided by the bank.

7.6. IT Strategy Committee of the Board: With a view to tracking the progress of the bank's IT initiatives, the SBI's central board constituted a technology committee of the board. The committee has played a strategic role in the bank's technology domain.

7.7. Remuneration Committee of the Board: It was constituted for evaluating the performance of whole time directors of the bank in connection with the payment of incentives, as per the scheme advised by Government of India.

It is found that in SBI, these committees are providing effective professional support in the conduct of board level business in key areas.

\section{STAKEHOLDERS SERVICES}

The SBI strongly believes that all stakeholders should have access to complete information on its activities, performance and product initiatives.

8.1. Shareholders: The SBI is providing different types of services and facilities to the shareholders. Share transfers in Physical form are processed and returned to the shareholders within stipulated time. SBI has the distinction of making uninterrupted dividend payment to the shareholders at an increasing rate for many years.

In accordance with the SEBI guidelines on green initiative in corporate governance, SBI is issuing annual report in electronic form to shareholders who opt for receiving the same in electronic form through their e-mails. To meet various requirements of the investors regarding their holdings, the Bank has a full-fledged department i.e. shares and bonds department and shares and bonds cells at the 14 local head offices.

8.2. Customers: With a large network and number of branches throughout India and abroad SBI is providing different types of services and facilities to the customers.

8.2.1 ATMs: State Bank group has in its stable, variants of ATMs. The number of ATMs of the SBI group was 25,005 in March 2011 and they increased to 27,286 in March 2012. The number of ATMs of SBI was 20,084 in 2011 and they are 22,141 in 2012. The total debit cards issued by SBI were 728 lakhs in 2011 and they increased to 910 lakhs in 2012.

8.2.2 Mobile Banking: There were 10.13 lakh registered mobile customers in 2011 and they increased to 36.45 lakhs in 2012. The customers were using the service with more than 1.20 lakhs daily transactions, around $46 \%$ of which are financial transactions amounting to Rs. 2.45 crores. SBI has launched mobile technology based prepaid payment services under the brand name of State Bank Mobi Cash.

8.2.3 Internet Banking: Internet banking service is available through www.onlinesbi.co.in for both retail and corporate customers of the bank. The number of customers in March 2011 was 62.57 lakhs and they increased to 
89.63 lakhs in March 2012. The number of transactions during 2010-2011 was 1437.46 lakhs and in 2011-12 it increased to 2610.32 lakhs.

8.2.4 Foreign Offices: The SBI is operating 173 branches in 34 countries, including 2 OBUs in India to run their operations on a common banking applications software, with their databases connected to a central data centre backed up by a synchronized disaster recovery site. All foreign offices use internet banking channel and 130 ATMs at various locations abroad cater to the bank's overseas customers with most of the ATMs connected to the centralized ATM switch in India.

8.2.5 Customer Complaints: The number of complaints received from the customers during the year 2010-11 was 30,904 and they increased to 462,381 during 2011-12.

8.3. Employees: The SBI had a total permanent staff strength of $2,15,481$ in the March, 2012. Of this, 80,404 (37.32\%) were officers, 95,715(44.42\%) were clerical staff and the remaining 39,362 (18.26\%) were sub-staff. It has been decided to recruit 9500 new clerical staff during the year 2012-13 to meet the growing business needs of the bank.

The SBI has transferred Rs. 49,518 crores to the SBI employee's pension fund trust from the special provision account, during the year 2011-12. An amount of Rs. 4531.83 crores is recognised as an expense towards the provident fund scheme of the bank. The bank has implemented a defined contribution pension scheme (DCPS). The contributions of the bank of Rs. 452.47 crores have been retained as a deposit with the bank and earn interest at the same rate as that of the current account of provident fund. An amount of Rs. 4531.33 crores (previous year 4775.74 crores) is provided towards long term employee benefits.

8.4. Society: The executive committee of the central board has approved a comprehensive policy for corporate social responsibility in August 2011. During the year 2011-12 the SBI has spent Rs. 71.18 crores for various social service activities like supporting education (Rs. 35.33 crores), Healthcare (Rs. 15.03 crores) and donations (Rs. 5.50 crores).

\section{DISCLOSURE AND TRANSPARENCY}

Disclosure and transparency are the important pillars of a corporate governance framework enabling adequate information flow to various stakeholders and leading to informed decisions. The SBI was implementing all the provisions of corporate governance and disclosure in the important and confidential information. Table 1 shows confidential information of SBI as a part of transparent disclosure of information.

9.1 Primary Business Segment Information of SBI: In the primary segment the treasury segment includes the entire investment portfolio and trading in foreign exchange contracts and derivative contracts; the corporate /whole sale banking segment comprises the lending activities of corporate accounts group, mid-corporate account group and stressed assets management group and the retail banking segment comprises of branches in national banking group, which primarily includes personal banking activities including lending activities to corporate customers. This segment also includes agency business and ATMs.

Table: 1 SBI Primary / Geographic Business Segments during 2011-12 (Rs. In crores)

\begin{tabular}{|l|r|r|r|r|r|r|}
\hline \multirow{2}{*}{$\begin{array}{c}\text { Business } \\
\text { Segment }\end{array}$} & \multicolumn{3}{|c|}{ 1. Primary Business Segment } & \multicolumn{2}{c|}{ 2. Geographic Segments } & \multicolumn{1}{c|}{$\begin{array}{c}\text { or } 2 \\
\text { Segments } \\
\text { Total }\end{array}$} \\
\cline { 2 - 6 } & Treasury & $\begin{array}{c}\text { Corporate } \\
\text { /Whole sale } \\
\text { Banking }\end{array}$ & $\begin{array}{c}\text { Retail } \\
\text { Banking }\end{array}$ & Domestic & Foreign & \\
\hline Revenue & 23,874 & 42,773 & 54,091 & $1,14,080$ & 6,659 & $1,20,739$ \\
& $(21,665)$ & $(32,935)$ & $(42,062)$ & $(91,086)$ & $(5,576)$ & $(96,662)$ \\
\hline Segment & $3,35,016$ & $3,94,421$ & $5,95,182$ & $11,55,176$ & $1,80,342$ & $13,24,621$ \\
Assets & $(3,10,524)$ & $(3,81,320)$ & $(5,22,699)$ & $(10,82,387)$ & $(1,41,348)$ & $(12,14,544)$ \\
\hline Segment & $1,96,222$ & $3,81,202$ & $6,28,479$ & $10,71,225$ & $1,80,342$ & $12,05,903$ \\
Liabilities & $(1,62,149)$ & $(3,67,495)$ & $(5,85,015)$ & $(10,17,401)$ & $(1,41,348)$ & $(11,14,659)$ \\
\hline
\end{tabular}

Figures in brackets are for previous year

9.2 Secondary Geographic Segments information of SBI: In this segment domestic operations are branches/ offices having operations in India. Foreign operations are branches/offices having operations outside India and offshore banking units having operations in India. 
The table-1 explains the revenue, assets and liabilities based on primary business segment with explaining treasury, corporate/wholesale banking and retail banking. The geographic segment explains domestic and foreign areas performance during 2010-11 and 2011-12.

9.3 Earnings per share of SBI: The basic earnings per share are computed by dividing the net profit after tax by the weighted average number of equity shares outstanding for the year. The net profit in 2010-11 was Rs. 8264.52 crores and it increased to Rs. 11,707.29 crores in 2011-12. Basic earning per share in 2010-11 is Rs. 130.16 and it increases to Rs. 184.31 in 2011-12.

9.4 Details of Different Provisions and Contingencies: The provisions and contingencies of SBI during 201112 are explained in table 2. The total provisions are Rs. 17,071.05 crores in 2010-11 and they increased to Rs. 19,866.25 crores during 2011-12.

Table: 2 Provisions and Contingencies

\begin{tabular}{|l|r|r|}
\multicolumn{2}{c}{ (Rs. in crores) } \\
\hline Provisions & $\mathbf{2 0 1 1 - 2 0 1 2}$ & $\mathbf{2 0 1 0 - 2 0 1 1}$ \\
\hline Current Tax & $6,335.37$ & $5,709.54$ \\
\hline Deferred Tax & 455.93 & 976.82 \\
\hline $\begin{array}{l}\text { Depreciation on } \\
\text { Investments }\end{array}$ & 683.28 & 646.75 \\
\hline Non-Performing Assets & $11,494.10$ & $8,415.44$ \\
\hline Restructured Assets & 51.76 & 376.65 \\
\hline Standard Assets & 978.81 & 976.60 \\
\hline Total & $19,866.25$ & $17,071.05$ \\
\hline
\end{tabular}

9.5 Details of Concentration of Advances, Exposures \& NPAs Information of SBI: Table 3 demonstrates the concentration of deposits, advances, exposures and NPAs information during 2010-11 and 2011-12. The table explains the operational weaknesses in the SBI regarding issue of advances to twenty largest borrowers, concentration of exposure with twenty largest borrowers and concentration of NPAs with four NPA accounts.

Table: 3 Concentration of Advances, Exposures \& NPAs

(Rs. in crores)

\begin{tabular}{|l|c|r|}
\hline Particulars & $2011-2012$ & $2010-2011$ \\
\hline $\begin{array}{l}\text { Concentration of Advances } \\
\text { (Twenty Largest Borrowers) }\end{array}$ & $83,199.80$ & $65,236.21$ \\
\hline $\begin{array}{l}\text { Concentration of Exposures } \\
\text { (Twenty Largest Borrowers ) }\end{array}$ & $2,13,774.62$ & $2,07,277.40$ \\
\hline $\begin{array}{l}\text { Concentration of NPAs } \\
\text { (Four NPA Accounts) }\end{array}$ & $2,931.51$ & 730.27 \\
\hline
\end{tabular}

\section{FINDINGS AND CONCLUSION}

The study found that, the SBI is implementing all the provisions of corporate governance according to the RBI/GOI directions. It is found that State Bank of India, the country's largest commercial bank, performed well in every aspect in terms of profits, assets, deposits, branches, employees and services to customers.

The study found that the SBI conducted different board meetings regularly to provide effective leadership, functional matters and monitors bank's performance. It is found that the SBI established clear documentation and transparent management processes for policy development, implementation, decisionmaking, monitoring, control and reporting.

Even though the SBI is showing good performance and implementing provisions of corporate governance, some lapses have to be rectified for increasing the performance.

The SBI is operating nearly 10 crores of customer accounts. Among them the net banking operating customers are 89.63 lakhs, mobile banking operating customers 36.45 lakhs, customers using ATMs are 910 lakhs. Though the customers operating e-banking are increasing every year, they are using e-banking for normal or minimum services.

It is suggested that consumer service committee must take initiative steps to increase online banking services through customer awareness programs and internet banking training programmes. It decreases customer's pressure on branches and it is useful to reduce customers waiting time in all branches.

The study found that customers complains are increased during the year 2011-12 $(4,62,381)$ when compared to the previous year 2010-2011 (30,904). Consumer service committee must take initiative steps to satisfactorily address customers' complaints. 
The study found that, concentration of advances to twenty largest borrowers increased from Rs. 65,236 crores in 2010-2011 to Rs. 83,199 crores in 2011-2012 indicating credit risk. It is suggested that the credit risk management should take necessary steps to minimize risks.

The study found that concentration of exposures to twenty largest borrowers has increased from Rs. 2,07,277.40 crores in 2010-11 to Rs. 2,13,774.62 crores in 2011-12 indicating credit risk. It is suggested that the central board should take immediate action to reduce the concentration of exposures.

It is found that the concentration of NPAs total exposure to top four NPA accounts was Rs. 730.27 crores in 2010-11 and it is increased to Rs. 2,931.51 crores in 2011-21 indicating credit risk. It is suggested that the credit risk management should take necessary steps to avoid this type of concentration of NPAs.

The SBI is conducting different types of social services activities in different sectors like education, healthcare and other areas as a part of social responsibility. The amount spent for this purpose was Rs. 71.18 crores only. It is suggested that the amount must be increased for social service activities to draw public attention.

Finally, this study concluded that, the corporate governance practice in the State Bank of India should improve for best investment policies, appropriate internal control systems, better credit risk management, better customer service and adequate automation in order to achieve excellence, transparency and maximization of stakeholder's value and wealth.

\section{REFERENCES}

[1] State Bank of India Annual Reports

[2] Websites : www.onlinesbi.com

[3] V.Leeladhar "Corporate governance in banks" RBI Bulletin December 2004

[4] Dr. Meghashree Agarwal Dadhich : 'Online banking services: an empirical study of banker's and customer's awareness about obs" ICFAI University, An overview of Banking," Nagarjuna Hills Publication, 2006.

[5] Krishna Lal Pandey, "Development of Banking in India since 1949," Scientific Book Agency, 1968. 